\title{
Smart Farming: Including Rights Holders for Responsible Agricultural Innovation
}

\author{
Kelly Bronson
}

\author{
"It is not from ourselves that we learn to be better") \\ than we are.
}

\author{
Wendell Berry \\ Novelist, poet, activist, and farmer
}

\begin{abstract}
This article draws on the literature of responsible innovation to suggest concrete processes for including rights holders in the "smart" agricultural revolution. It first draws upon historical agricultural research in Canada to highlight how productivist values drove seed innovations with particular consequences for the distribution of power in the food system. Next, the article uses document analysis to suggest that a similar value framework is motivating public investment in smart farming innovations. The article is of interest to smart farming's decision makers (from farmers to governance actors) and a broader audience - anyone interested in engendering equity through innovation-led societal transitions.
\end{abstract}

\section{Introduction}

This article begins from the foundational premise that values are endemic to innovation. This premise goes against the dominant view in which innovation design (and to a certain extent governance) is seen as highly technical and objective work that addresses a narrow set of practical problems. Innovations not only solve design problems but they also reorder society, fostering particular distributions of power and authority and giving rise to some social realities, necessarily at the expense of others (Winner, 1986). Therefore, innovating with foresight requires having broad conversations early on in the innovation process about the kinds of societies we want to enable (or disable) (Stilgoe et al., 2013). What kind of society do we want and what innovation features will get us there? Such a question cannot be answered technocratically; instead, answering values-based questions requires the wide involvement of rights holders, not least because engineers and technical policy actors are highly specialized experts whose life experiences and training do not equip them to anticipate the broad ethical and political implications of innovations (Ottinger \& Cohen, 2011; Sarewitz, 2004; Yearly, 2004). Unlike "stakeholders", or anyone with a stake in the innovation process, rights holders might be thought of as those for whom the realization of their livelihood is inextricably linked to governance decisions.
This article details emergent "smart" agricultural innovations in their wider historical context - framed in continuity with longstanding values and goals, which have driven agricultural innovations that have both delivered a productive but also an inequitable global food system (Lang \& Heasman, 2004; Patel, 2008). The socalled "smart farming" approach is one where farm decisions are informed by big data collected and made sense of by intelligent machines (Wolfert et al., 2017). It is also referred to as digital agriculture, precision agriculture or big data in agriculture (Bronson \& Knezevic, 2016a, 2016b). Ultimately, this article uses research in the burgeoning area of scholarship and practice called "responsible innovation" to lay out potential inclusive decision processes that could help engender justice and equity through current innovation-led agricultural transformations.

\section{What is the "Smart" Farming "Revolution"?}

Farming is said to be undergoing a "smart" technology "revolution" (Datafloq, 2015). John Deere now fits each of its "precision" tractors with sensors that collect data about soil and crop conditions. The software used in John Deere's tractor is proprietary and the data it collects are not openly accessible. Instead, the corporation invites farmers to subscribe (and pay) for access to information it generates from aggregated datasets and 


\section{Smart Farming: Including Rights Holders for Responsible Agricultural Innovation}

Kelly Bronson

which is accessible using a "My Farm Manager" mobile application. Proponents of smart agricultural innovations such as precision tractors suggest that these tools introduce incredible business efficiency into farming. For example, farmers can use big data to create a fertilizer application map that allows them to continuously vary fertilizer rates as a crop is being seeded.

Farming has been empirically driven for over a century though arguably the "big" data of smart farming is different from historical information gathering in terms of its volume. As early as the 1920s, Agriculture Canada scientists meticulously recorded wheat yields and weather patterns on experimental farms, all with the goal of increasing crop productivity. Today's empirical approach is also marked as different by the sophisticated analytical capacity of computer algorithms, which are written to use voluminous data for generating particular, or even entirely unexpected insights (Gitelman \& Jackson, 2013). Big data is thought to improve upon human limitations such that it represents a revolution in the scientific approach (Anderson, 2018).

Corporations and governments evidently recognize the economic potential in smart innovations applied to food production. One only has to look at Monsanto Corporation's purchasing habits. In 2013, Monsanto bought the digital tool developer Climate Corporation for $\$ 930$ million USD. Under a platform called Integrated Field Systems (IFS) released in 2014, Monsanto offers farmers a suite of digital tools for collecting and analyzing farm data. Farmers are being encouraged to use Monsanto's IFS tools that collect data about soil conditions, weed varieties, and weather. Monsanto's computer software, farmers are told, will generate information that can help minimize financial risk and streamline business decision making. Beyond these benefits to the farmer, there are likely secondary benefits to the corporation from the collection of agricultural data. Monsanto-derived "Weed ID" is an app that allows farmers to map novel weeds in digital software made available to them without charge. While helping farmers identify unknown weeds, Monsanto can use farm-level data to promote its proprietary chemicals and farmers' (qua field researchers') data collection to drive research and development. Whether the individual farmer benefits commensurately with the corporation is an ethical question that has yet to be answered and is not unlike pressing questions surrounding the use of social media data (Elmer et al., 2015).
It is clear that the Canadian federal government recognizes the economic gains presented by smart agricultural innovations: it is investing significant public money into the development of innovations in data and machine intelligence applied to agriculture in the hope that they will help meet sustainability challenges (through emission reductions) and demand for jobs among Canadians (GOC, 2017). In February 2017, the federal "Barton Report" flagged agricultural innovation as having high potential to drive economic growth and societal wellbeing.

While there are undoubtedly opportunities associated with smart farming innovations beyond economic gains (e.g., environmental gains through reduced input use, see Wolfert et al., 2017), there are potentially negative outcomes, especially socio-ethical implications for humans and non-humans (Carbonell, 2016; Driessen \& Heutinck, 2015; Millar, 2000). To date, only a handful of studies have looked at these potential implications of smart farming. It is possible, however, to make inferences from the application of smart innovations in other sectors. The World Economic Forum has extrapolated from the automotive sector to predict wide-scale "technological unemployment" resulting from the application of automation in sectors such as agriculture (WEF, 2016). Changes in rural work populations could have a major impact on social cohesion in many communities and on the livelihoods of many labourers (Carolan, 2016). Studies of the application of smart innovations to the dairy sector in Australia reveal a reshaping of the practice of farming, with less hands-on management and more "data-driven" decisions (Eastwood et al., 2012). Given the ethical issues presented with the "mining" of health data, we can infer that the use of environmental big data collected by precision tractors will present challenges in determining which data to collect in order to meet societal not just corporate goals, and challenges in determining how much access to societally important datasets to enable. Indeed, the United Nations' Global Open Data for Agriculture and Nutrition (GODAN; godan.info) programme calls for open access to agricultural data as a basic right because they feel it will help with the pressing humanitarian crisis that is global food insecurity. The bulk of research on innovation and society would suggest that, no matter what we know about smart farming in particular, it is inevitable that it will produce both benefits and risks (Beck, 1992). 


\section{Smart Farming: Including Rights Holders for Responsible Agricultural Innovation}

Kelly Bronson

\section{When Old Is New: Smart Agriculture's Value Frameworks}

Innovations by definition offer technical novelties and ingenuity, but they often reproduce, rather than disrupt, societal relationships of power and authority (Marvin, 1988). Consider briefly, for example, the history of seed science in Canada (but see Bronson, 2015, for a more detailed treatment of the subject). In the early to mid-20th century, the Canadian federal government devoted money to establishing seed research or plant breeding housed in universities across the country (Kuyek, 2000). The innovative hybrid seeds that came out of these research networks - ones that included farmer/on-farm experimentation - were driven by the technical goal of boosting production (and under certain adverse environmental conditions). Hardworking and clever scientists developed drought-tolerant and dwarf plant varietals in staple commodity crops such as corn (GOC, 2009). Because these seeds, as well as their successors - genetically engineered seed systems - were designed to work in tandem with chemical fertilizers and pesticides, their uptake led to a concentration of market power among already-powerful chemical corporations. This market distortion became further exaggerated as the chemical corporations bought up seed research facilities and refigured themselves as "life sciences" corporations responsible for multiple agricultural inputs (Howard, 2015; Qualman, 2005). Smaller family farmers, unable to compete by taking on the economic risks associated with increasing productivity (such as buying certified seeds) have slowly been incorporated into larger farms such that commercial farms now dominate the Canadian rural landscape (Statistics Canada, 2016). This pattern of "rationalization" was laid out as a policy goal in the Government of Canada's 1969 Task Force on Agriculture, though today's leading agencies (e.g., the United Nations) call out the irrationality of food system reliance on corporate farming (see IPES-Food, 2016). Yet Canadian hybrid seed innovators were never intentionally working to displace farmers; rather, they were myopically focused on boosting yield and were not working with a full view of what the future of agriculture and rural living would look like guided by productivist values (see Kneen, 1992).

Current smart farming research and investment decisions appear to turn on the same agricultural values and goals as those that guided hybrid and biotechnology seed innovation: boosting yield through intensive agricultural production of staple commodities destined for distant markets. At the global level, the World
Bank's Agriculture Action Plan (2015) and Climate Action Plan (2016) describe how the application of smart agricultural innovations promise to make input-intensive agricultural practices (e.g., irrigation and livestock farming) more precise and economically efficient. These reports explicitly lay out the need to further the established priorities of dominant stake-holders in the global food system such as large agribusinesses and philanthropic organizations (e.g., The Gates Foundation). Similarly, a corporate video - Farm Forward that is meant to project John Deere's vision for the future of its precision agriculture equipment shows images of fully automated tractors, centrally controlled sensing and monitoring and other imagined (not yet realized) innovations supporting large-scale and mono-crop production. The American farmer of the future, like "Terry" pictured in this campaign video, is able to farm from the comfort of his living room where these tools give him a god's eye view of his fields (translated into data points); this is a positive view on the displacement of farm labourers by innovations in automation.

Smart farming research and investment decisions in Canada also appear motivated by those problems facing larger commodity-crop farmers, at least according to a survey of prominent farm papers. Farm papers are read by a variety of food system actors and are powerful spaces where agricultural advice is shared and technological forecasting happens. A document scan of five farm papers over a six-month period (Dec. 2016-May 2017) reveals that every article mentioning smart agricultural tools - from drones to phone apps - enacts a dominant "foodscape", which is a place where food is produced, prepared, or generally where people gather meaning about food and its production (Winson, 2005). Only large, input-intensive farms are pictured in the images or described in the copy of these articles. One article on a Lightbar system for GPS tractors suggests that this innovation allows the farmer that same omniscience as John Deere imagines for Terry: a "heads up" and remote view of potential natural and subsequently financial risks.

It appears that smart agricultural innovations being developed and deployed in the public sector are being guided by productivist values. Current government investments seem to presuppose, and thus tacitly promote, large-scale capital-intensive farms. As example, in 2016, the federal government invested nearly half a million dollars into the corporate development of a "clean" seeder meant to reduce emissions as well as, according to Minister of Innovation Navdeep Bains, 


\section{Smart Farming: Including Rights Holders for Responsible Agricultural Innovation}

Kelly Bronson

"modernize" the farm and grow jobs for "skilled workers" (Flamini, 2016). Tools like this are developed for large-scale farmers requiring newer and larger machinery, who can weather financial risk by distributing costs over thousands of acres. The CX-6 Smart Seeder will be costly in terms of capital and also in terms of managerial time - a farmer untrained in computer science is ill-equipped to understand, tinker with, and fix such a device (Solon, 2017). While not an explicit directive vis-à-vis such public investments, training a rural workforce in Internet technology skills (e.g., coding) is obviously a key part of agricultural "modernization"; said differently, smart farming innovations are intended to serve farmers to some extent by replacing them. As part of a larger, qualitative research project on "smart" farming in Canada, the author interviewed engineers and data scientists in government and industry, as well as farmers, to sketch some of the societal transitions enabled by these emergent innovations. One data scientist working with Agriculture and Agri-food Canada said that "intelligent" tractors are the future: "it's just progression... where you're able to make quick decisions, or something's able to make those decisions for you."

\section{Inclusion for Ethical Innovation: Recommendations for Smart Agriculture's Decision Makers}

Smart farming innovation in Canada currently has a blind spot: the needs and concerns of smaller- and medium-sized labour-intensive farms. To many decisionmakers, this area of "undone science" (Frickel et al., 2010) is not controversial but reflects the market, with technological trajectories, for example, following those who can pay. The data scientist quoted above puts it this way:

"I suspect some intermediary of value-added service provider is taking [the data we prepare] and doing something neat with it. We don't get into the sandbox, we just let industry and private sector deal with it and they go where they're gonna make the money."

It is now firmly established in the innovation literature that technology development cannot be understood without reference to market demands (Palm \& Hansson, 2004), and that agricultural innovations become embedded within political economic infrastructures (see Hellstrom, 2003). A very recent study by Eastwood and colleagues (2017) shows how the desire to anticipate and prevent potential negative consequences from smart dairying in New Zealand is complicated by the commercially-driven nature of these innovations.
That smart innovations appear set to advantage alreadypowerful players in the food system in Canada may indeed be a market reality but it is simultaneously a democratic problem. The Canadian government therefore has an opportunity vis-à-vis smart agricultural innovation: the investment of public money can be used to advance larger societal interests and guard against the sequestration of power among the few (Jasanoff, 2017). Given historical experience with agricultural innovations, we know that technological equity and broad social progress has to be secured through careful and ethical decisions taken by key players in the innovation ecosystem.

An important question is, thus: How do smart farming's decision makers anticipate and attend to the needs and concerns of a wide variety of rights holders in the food system? One suggestion, drawn from an area of scholarship and practice called responsible innovation, is to stage reasoned deliberations on technological needs and concerns between historically marginalized food system actors and prominent decision makers in government. Responsible innovation is a rubric for guiding innovation toward socially and ethically acceptable ends (Stilgoe et al., 2013) with links to European technology assessments as well as to corporate social responsibility (Iatridis \& Schroeder, 2016). Unlike corporate social responsibility, responsible innovation is meant to seek redress for ethical considerations often made invisible within an innovation's ecosystem, including existing inequities; this means that, unlike with corporate social responsibility methods for engaging "stakeholders", responsible innovation prioritizes the inclusion of rights holders historically marginalized in innovation decision processes (e.g., under-represented genders, see Wickson \& Carew, 2014). As well, unlike technology assessments that consider pros and cons or risks and benefits, responsible innovation leads with broader and valuesbased inquiries into innovations in society.

Table 1 provides three concrete suggestions for Canadian smart farming's decision makers that build closely off of a recent study conducted on smart dairying in New Zealand (Eastwood et al., 2017), which in turn builds off of foundational literature on responsible innovation $(\mathrm{Gu}-$ ston et al., 2014; Stilgoe et al., 2013; see also Macnaghten, 2016; Macnaghten et al., 2014, c.f. Asveld et al., 2015; Bronson, 2015). There is also a now well-developed body of literature, some of which comes from key Canadian scholars such as Michael Burgess, on the methodological particulars of how to deliver a deliberative process for assessing societal needs and concerns around innovation (see Blacksher et al., 2012; Einsiedel et al., 2001; Longstaff \& Burgess, 2009; O’Doherty et al., 2012). 


\section{Smart Farming: Including Rights Holders for Responsible Agricultural Innovation} Kelly Bronson

Table 1. Concrete suggestions for decision makers involved with smart farming innovation, inspired by Eastwood and colleagues (2017)

\begin{tabular}{lll}
\hline Inclusive Innovation Action & Description & Potential Methods or Activities \\
\hline Involving rights holders & $\begin{array}{l}\text { Get a range of end users and citizens } \\
\text { involved in deliberations meant to glean } \\
\text { their concerns and their knowledge of } \\
\text { potential social and ethical risks. Attend } \\
\text { to recruiting small landholders and } \\
\text { alternative producers. }\end{array}$ & $\begin{array}{l}\begin{array}{l}\text { Citizens juries or workshops deploying } \\
\text { methods aimed at gathering critical feedback } \\
\text { (i.e. nonsensus) }\end{array} \\
\text { Private sector engagement }\end{array}$ \\
$\begin{array}{ll}\text { Engage private sector partners in public- } \\
\text { industry research in conversations about } \\
\text { public needs (established via the } \\
\text { deliberations with rights holders) }\end{array}$ & $\begin{array}{l}\text { Feedback from citizens and end users about } \\
\text { what society they want innovations to help } \\
\text { deliver is fed to private sector actors in plain } \\
\text { language reports }\end{array}$ \\
\hline Encouraging feedback and mutual design & $\begin{array}{l}\text { Designers and multiple stakeholders } \\
\text { engaged in mutual learning and open } \\
\text { R\&D projects }\end{array}$ & $\begin{array}{l}\text { Open innovation; user-centred design; online } \\
\text { feedback on public-sector innovations } \\
\text { "upstream" }\end{array}$ \\
\hline
\end{tabular}

As illustrated in the case example of Canadian seed science given in this article, decision makers are often firmly entrenched within hegemonic value frameworks, in part because they are themselves members of the dominant groups (Palm \& Hansson, 2006). Moreover, given the nature of gaining specialized expertise in technical policy making - usually gathered through a long process of enculturation in domain-specific knowledge (Collins, 2007) - technology developers are rarely conscious of the wider effects of their products, perhaps especially on historically marginalized players in the innovation ecosystem (Ottinger \& Cohen, 2013).

Thus, the inclusion of rights holders in broad, valuesbased inquiries related to technology development has been suggested as a method for improving outcomes (ones engendering equity) and also for improving trust in the innovation process (Asveld et al., 2015). Wickson and Carew (2014) have shown that open design projects can enable interaction between wider social values and technological potential; at the design stage, innovations are not yet entrenched into infrastructures (e.g., regulations) or cultural habits, which means early intervention can help mitigate the dreaded "lag" between proscriptive policy making and rapid technological change (Ogburn, 1957).

\section{Conclusion}

Amidst what appears to be incredible enthusiasm for a "smart" agricultural revolution, significant questions are emerging about how digital innovations, such as tractors that collect data and algorithms "mining" them, ought to be understood and managed. This article has drawn on the rubric of responsible innovation to make suggestions for those driving smart innovation to critically reflect upon the value frameworks motivating innovation for the ways in which these may be privileging already privileged actors in the food system. There is an indication that innovations in big data and machine intelligence, just as with genetically engineered seed systems, may enable by their very design consolidation of power among agribusinesses. For example, Monsanto's Fieldscripts, a platform for integrating farm-level big data, makes use of a proprietary algorithm that identifies which seeds are the "best match" for a field's conditions and then creates a variable rate seeding "prescription". The route by which the algorithm functions to arrive at a "prescription" is completely opaque, protected (understandably) as corporate intellectual property, and there is a similar lack of transparency around the profit-generating uses of Fieldscripts big data. Moreover, the "prescription", administered by a Monsanto employee/seed dealer, consists of recommendations that purportedly match the conditions of a farmer's field to one of Monsanto's hybrid seeds and proprietary chemicals - products bought as part and parcel of this "prescription", also through the seed dealer. To use FieldScripts, then, farmers are necessarily tethered to Monsanto Corporation who stands to gain enormously from the bundling of precision machinery, data, seeds, and chemicals. 


\section{Smart Farming: Including Rights Holders for Responsible Agricultural Innovation}

Kelly Bronson

Corporations have a legal mandate to maximize profit but, especially in publicly funded research, the government has a democratic mandate to ensure that the technologies it helps to develop contribute to the good of society as a whole and not just the interests of the already rich and powerful. It is not yet obvious the extent to which smaller and alternative producers will be increasingly marginalized or sustained by a smart agricultural revolution; however, it does seem that Canadian smart farming decision makers are captured by productivist values and are focusing their efforts on streamlining economic decisions and promoting high yields. Obfuscated in these "imaginaries" (Jasanoff, 2015) for smart agricultural innovations are questions about rural livelihood and food justice: What kind of rural societies do a variety of Canadians want to sustain? What farm strategies are important to Canadians? Certainly, recent reports at the level of the United Nations suggest the need for a "multi-functional" approach to food production in food systems around the world (see IPES-Food, 2016). Values-based questioning ought to be foregrounded, as a normative matter, in inclusive processes of decision-making on smart agriculture.

The tag line for the 1939 World's Fair was, "Science discovers, technology creates, man adapts." But innovations do not drop from the sky; rather, certain people steer innovation directions, within political economic contexts and, importantly, cultural values. Right now (or even yesterday) is the time to use inclusive innovation processes to critically reflect upon the wider contexts of smart agricultural innovation - before the difficult-toundo systems surrounding these tools become solidified (Bowker \& Star, 1999; Bronson, 2015).

\section{Acknowledgements}

The author acknowledges the Social Sciences and Humanities Research Council for funding the broader research project which helps to inform this article. As well, the author is thankful for the hard work of two research assistants (Megan Beaulieu and Matthew Zucca) and the helpful comments of a reviewer who weighed in on an earlier draft.

\section{About the Author}

Kelly Bronson is an Assistant Professor in the Faculty of Social Sciences and the Institute for Science, Society, and Policy at the University of Ottawa, Canada. She is a social scientist studying sciencesociety tensions that erupt around controversial technologies and their governance - from GMOs to big data. Her research aims to bring community values into conversation with technical knowledge in the production of evidence-based decision-making. She has published her work in regional Journal of New Brunswick Studies), national (Canadian Journal of Communication), and international journals (Journal of Responsible Innovation, Big Data and Society).

\section{References}

Anderson, C. 2008. The End of Theory: The Data Deluge Makes the Scientific Method Obsolete. Wired, June 23, 2008. Accessed February 15, 2018:

https://www.wired.com/2008/06/pb-theory/

Beck, U. 1992. Risk Society: Towards a New Modernity. London, UK: Sage Publications.

Blacksher, E., Diebal, A., Forest, P. G., Goold, S. D., \& Abelson, J. 2012. What is Public Deliberation? The Hastings Center Report, 42(2): 14-17.

http://doi.org/10.1002/hast.26

Bronson, K., \& Knezevic, I. 2016a. Food Studies Scholars Can No Longer Ignore the Rise of Big Data. Canadian Food Studies, 3(1): 9-19.

http://dx.doi.org/10.15353/cfs-rcea.v3i1.138

Bronson, K., \& Knezevic, I. 2016b. Big Data in Food and Agriculture. Big Data and Society, 2(1): 1-5.

https://doi.org/10.1177/2053951716648174

Bronson, K. 2015. Responsible to Whom? Seed Innovations and the Corporatization of North American Agriculture. Journal of Responsible Innovation, 2(1): 62-77.

https://doi.org/10.1080/23299460.2015.1010769

Bowker, G. C., \& Star, S. L. 1999. Sorting Things Out: Classification and Its Consequences. Cambridge, MA: MIT Press.

Carbonell, I. 2016. The Ethics of Big Data in Agriculture. Internet Policy Review, 5(1).

https://doi.org/10.14763/2016.1.405

Carolan, M. 2016. Publicising Food: Big Data, Precision Agriculture, and Co-Experimental Techniques of Addition. Sociologia Ruralis, 57(2): 135-154.

https://doi.org/10.1111/soru.12120

Collins, H. M. 2007. Rethinking Expertise. Chicago, IL: University of Chicago Press. 


\section{Smart Farming: Including Rights Holders for Responsible Agricultural Innovation}

\section{Kelly Bronson}

Driessen, C., \& Heutinck, L. F. M. 2015. Cows Desiring to Be Milked? Milking Robots and the Co-Evolution of Ethics and Technology on Dutch Dairy Farms. Agriculture and Human Values, 32(1): 3-20. https://doi.org/10.1007/s10460-014-9515-5

Flammini, D. 2016. Government of Canada Invests $\$ 425 \mathrm{~K}$ into Precision Agriculture. Farms.com, November 25, 2016. Accessed February 15, 2018:

http://www.farms.com/ag-industry-news/government-of-canadainvests-425k-into-precision-agriculture-927.aspx

Hellstrom, T. 2003. Systemic Innovation and Risk: Technology Assessment and the Challenge of Responsible Innovation. Technology in Society, 25(3): 369-384.

https://doi.org/10.1016/S0160-791X(03)00041-1

Iatridis, K., \& Schroeder, D. 2016. Responsible Research and Innovation in Industry: The Case for Corporate Responsibility Tools. Cham, Switzerland: Springer International Publishing. http://doi.org/10.1007/978-3-319-21693-5

Jasanoff, S. 2017. The Ethics of Invention, Technology and the Human Future. New York: Norton Publishing.

O’Doherty, K., Gauvin, F.-P., Grogan, C., \& Friedman, W. 2012. Implementing a Public Deliberative Forum. The Hastings Center Report, 42(2): 20-23.

Solon, O. 2017. A Right to Repair: Why Nebraska Farmers Are Taking on John Deere and Apple. The Guardian, March 6, 2017. Accessed February 15, 2018:

https://www.theguardian.com/environment/2017/mar/06/nebras ka-farmers-right-to-repair-john-deere-apple

Einsiedel, E. F., Erling, J., \& Breck, T. 2001. Publics at the Technology Table: The Consensus Conference in Denmark, Canada, and Australia. Public Understanding of Science, 10(1): 83-98. https://doi.org/10.3109/a036857

Elmer, G., Langlois, G., \& Redden, J. 2015. Compromised Data: From Social Media to Big Data. London: Bloomsbury.

GOC. 2017. Budget 2017: Skills and Innovation. Ottawa: Government of Canada (GOC).

http://www.budget.gc.ca/2017/docs/bb/brief-brefen.html\#section 1

GOC. 2017. Unleashing the Growth Potential of Key Sectors. Ottawa: Government of Canada (GOC), Advisory Committee on Economic Growth.

https://www.budget.gc.ca/aceg-cce/pdf/key-sectors-secteurscles-eng.pdf

Frickel, S., Gibbon, S., Howard, J., Kempner, J., Ottinger, G., \& Hess, D. 2010. Undone Science: Charting Social Movement and Civil Society Challenges to Research Agenda Setting. Science, Technology, \& Human Values, 35(4): 444-473. https://doi.org/10.1177/0162243909345836

Guston, D. H., Fisher, E., Grunwald, A., Owen, R., Swierstra, T., \& van der Burg, S. 2014. Responsible Innovation: Motivations for a New Journal. Journal of Responsible Innovation, 1(1): 1-8. https://doi.org/10.1080/23299460.2014.885175

Hansen, T., \& Coenen, L. 2015. The Geography of Sustainability Transitions: Review, Synthesis and Reflections on an Emergent Research Field. Environmental Innovation and Societal Transitions, 17: 92-109.

https://doi.org/10.1016/j.eist.2014.11.001
IPES-Food. 2016. From Uniformity to Diversity: a Paradigm Shift From Industrial Agriculture to Diversified Agroecological Systems. Brussels: International Panel of Experts on Sustainable Food Systems (IPES-Food).

Kinchy, A. 2012. Seeds, Science and Struggle. Cambridge, MA: MIT Press.

Kneen, B. 1992. The Rape of Canola. Toronto: Dundurn Press.

Kuyek, D. 2000. Lords of Poison: The Pesticide Cartel. Grain, June 15, 2000. Accessed February 15, 2018:

https:/ / www.grain.org/e/293

Lang, T., \& Heasman, M. 2004. Food Wars: The Global Battle for Mouths, Minds and Markets. London: Routledge.

Longstaff, H., \& Burgess, M. M. 2009. Recruiting for Representation in Public Deliberation on the Ethics of Biobanks. Public Understanding of Science, 19(2): 212-224.

https://doi.org/10.1177/0963662508097626

Macnaghten, P. 2016. Responsible Innovation and the Reshaping of Existing Technological Trajectories: The Hard Case of Genetically Modified Crops. Journal of Responsible Innovation, 3(3): 282-298. https://doi.org/10.1080/23299460.2016.1255700

Macnaghten, P., Owen, R., Stilgoe, J., Wynne, B. Azevedo, A., de Campos, A., Chilvers, J., Dagnino, R., di Giulio, G., Frow, E., Garvey, B., Groves, C., Hartley, S., Knobel, M., Kobayashi, E., Lehtonen, M., Lezaun, J., Mello, L., Monteiro, M., Pamplona da Costa, J., Rigolin, C., Rondani, B., Staykova, M., Taddei, R., Till, C., Tyfield, D., Wilford, S., \& Velho, L. 2014. Responsible Innovation Across Borders: Tensions, Paradoxes and Possibilities. Journal of Responsible Innovation, 1(2): 191-199.

http://doi.org/10.1080/23299460.2014.922249

Marvin, C. 1988. When Old Technologies are New, Thinking about Electric Communication in the Late 19th Century. Oxford: Oxford University Press.

Millar, K. M. 2000. Respect for Animal Autonomy in Bioethical Analysis: The Case of Automatic Milking Systems (AMS). Journal of Agricultural and Environmental Ethics, 12(1): 41-50. https://doi.org/10.1023/A:1009548025408

Moffat, M. 2017. Inclusive Innovation: The Importance of Place. Paper presented at the Inclusive Innovation Workshop, University of Ottawa, September 8, 2017.

O’Doherty, K., Gauvin, F.-P., Grogan, C., \& Friedman, W. 2012. Implementing a Public Deliberative Forum. The Hastings Center Report, 42(2): 20-23. http://doi.org/10.1002/hast.28

Ogburn, W. F. 1957. Cultural Lag as Theory. Sociology \& Social Research, 41:167-174.

Ottinger, G., \& Cohen, B. 2011. Technoscience and Environmental Justice. Cambridge, MA: MIT Press.

Owen, R., Macnaghten, P., \& Stilgoe, J. 2012. Responsible Research and Innovation: From Science in Society to Science for Society, with Society. Science and Public Policy, 39(6): 751-760. https://doi.org/10.1093/scipol/scs093

Palm, E., \& Hansson, S. O. 2006. The Case for Ethical Technology Assessment (eTA). Technological Forecasting and Social Change, 73(5): 543-558. https://doi.org/10.1016/j.techfore.2005.06.002 


\section{Smart Farming: Including Rights Holders for Responsible Agricultural Innovation}

Kelly Bronson

Patel, R. 2008. Stuffed and Starved, Power and the Hidden Battle for the World Food System. London: Portobello Books.

Sarewitz, D. 2004. How Science Makes Environmental Controversies Worse. Environmental Science and Policy, 7(4): 385-403.

https://doi.org/10.1016/j.envsci.2004.06.001

Soete, L. 2017. Reflections on Inclusive Innovation. Paper presented at the Inclusive Innovation Workshop, University of Ottawa, September 8, 2017.

Stilgoe, J., Owen, R., \& Macnaghten, P. 2013. Developing a Framework for Responsible Innovation. Research Policy, 42(9): 1568-1580. https://doi.org/10.1016/j.respol.2013.05.008

Statistics Canada. 2016. 2016 Census of Agriculture. Ottawa: Statistics Canada.

https://www.statcan.gc.ca/eng/ca2016

Winson, A. 2004. Bringing Political Economy into the Obesity Epidemic. Agriculture and Human Values, 21(4): 299-312.

https://doi.org/10.1007/s10460-003-1206-6

WEF. 2016. The Future of Jobs. Geneva: World Economic Forum (WEF).

https://www.weforum.org/reports/the-future-of-jobs

Wickson, F., \& Carew, A. L. 2014. Quality Criteria and Indicators for Responsible Research and Innovation: Learning from Transdisciplinarity. Journal of Responsible Innovation, 1(3): 254-273.

http://doi.org/10.1080/23299460.2014.963004

Wolfert, S., Ge, L., Verdouw, C., \& Bogaardt, M.-J. 2017. Big Data in Smart Farming: A Review. Agricultural Systems, 153: 69-80.

https://doi.org/10.1016/j.agsy.2017.01.023

World Bank. 2015. Agriculture Action Plan. Washington: World Bank.

World Bank. 2016. World Bank Group Climate Change Action Plan 2016-2020. Washington: World Bank.

Yearly, S. 2004. Making Sense of Science. London: Sage Publications.

Citation: Bronson, K. 2018. Smart Farming: Including Rights Holders for Responsible Agricultural Innovation. Technology Innovation Management Review, 8(2): 7-14. http://doi.org/10.22215/timreview/1135

Keywords: big data, machine intelligence, automation, agriculture, smart agriculture, responsible innovation, technological values, power 


\section{Academic Affiliations and Funding Acknowledgements}

Canadà
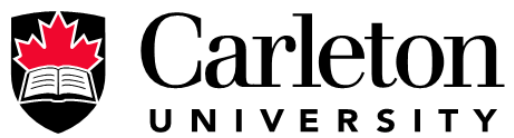

U N I V E R S I T Y

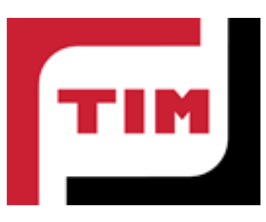

The Federal Economic Development Agency for Southern Ontario (FedDev Ontario; feddevontario.gc.ca) is part of the Innovation, Science and Economic Development portfolio and one of six regional development agencies, each of which helps to address key economic challenges by providing regionallytailored programs, services, knowledge and expertise.

- The TIM Review receives partial funding from FedDev Ontario's Investing in Regional Diversification initiative.

Technology Innovation Management (TIM; timprogram.ca) is an international master's level program at Carleton University in Ottawa, Canada. It leads to a Master of Applied Science (M.A.Sc.) degree, a Master of Engineering (M.Eng.) degree, or a Master of Entrepreneurship (M.Ent.) degree. The objective of this program is to train aspiring entrepreneurs on creating wealth at the early stages of company or opportunity lifecycles.

- The TIM Review is published in association with and receives partial funding from the TIM program. 